\title{
Allozymic variation in the clam genus Eurhomalea (Bivalvia: Veneriidae) along southern South American coast
}

\author{
Variación alozímica en el género de almejas Eurhomalea \\ (Bivalvia: Veneriidae) a lo largo de la costa sur de Sudamérica \\ M.H. GALLARDO ${ }^{1}$, C. GONZÁLEZ ${ }^{1}$, C. MENA ${ }^{1}$, \\ B. LOMOVASKY ${ }^{2}$, E. MORRICONI ${ }^{2} \&$ E. CLASING ${ }^{3}$ \\ ${ }^{1}$ Instituto de Ecología y Evolución, ${ }^{3}$ Instituto de Biología Marina, Universidad Austral de Chile, \\ Casilla 567, Valdivia, Chile; e-mail: mgallard@uach.cl \\ ${ }^{2}$ Centro Austral de Investigaciones Científicas (CADIC-CONICET), Casilla de Correos 92 \\ (V9410BFD) Ushuaia, Tierra del Fuego, Argentina
}

\begin{abstract}
The correspondence between allozymic variation and specific differentiation was studied in four populations corresponding to the three nominal, allopatric species of clam genus Eurhomalea (E. rufa, E. lenticularis, E. exalbida) described for southern South America. Allozyme variation scored in 12 loci was high as indicated by heterozygosity levels (15.8-20.7\%) and by the presence of only three monomorphic loci $(H k-2, I c d-2$, and $X d h-1)$. These high estimates of allelic variability were influenced by the low levels of interspecific genetic similarity $(I=0.64)$ and for the high conspecific values of genetic identity observed. The high estimates of substructuring found at the species level $\left(\mathrm{F}_{\mathrm{ST}}=0.39\right)$ contrasted with the low differentiation $\left(\mathrm{F}_{\mathrm{ST}}=0.027\right)$ and high migration rate $(\mathrm{Nm}=9)$ existing among conspecific samples. Diagnostic allele fixation coinciding with specific recognition was recorded at locus $H k-1$ whereas nearly-fixed differences at loci (Adh, $\alpha-G p d$, Icd-1, $L d h, O d h, P g m-3)$ differed sharply in frequency among species. The Wagner procedure and the neighborjoining algorithm produced a similar tree topology highly related to the geographic distance and to their taxonomic recognition. The lack of coincidence between patterns of allozymic variation and the two distinctive shell morphs (flat and globoid) occurring in E. exalbida from Ushuaia bay do not support their taxonomic recognition.
\end{abstract}

Key words: allozymic variation, Eurhomalea, genetic structure, taxonomic status.

\section{RESUMEN}

Se estudió la correspondencia entre la variación bioquímica y la diferenciación específica en cuatro poblaciones correspondientes a las tres especies nominales y alopátricas en las almejas del género Eurhomalea $(E$. rufa, E. lenticularis, E. exalbida) descritas para la zona sur de Sudamérica.

La variación alozímica registrada en 12 loci fue alta como lo indican los altos niveles de heterocigosidad $(15,8-20,7 \%)$ y por la presencia de solo tres loci monomórficos (Hk-2, Icd-2 y Xdh-1). Esta alta estimación de variabilidad alélica influyó en los bajos niveles de similitud genética interespecífica $(I=0,64)$ y en los altos valores de identidad genética conespecífica observados. El alto grado de subestructuración poblacional interespecífica $\left(\mathrm{F}_{\mathrm{ST}}=0,39\right)$ contrasta con la poca diferenciación $\left(\mathrm{F}_{\mathrm{ST}}=0,027\right)$ y la alta tasa de migración $(\mathrm{Nm}$ =9) existente a nivel intraespecífica. Coincidiendo con la situación específica de estas tres especies, se observó fijación alternativa de alelos en el locus $H k-1$ mientras que los loci (Adh, $\alpha-G p d, I d h-1, L d h, O d h$, $P g m-3)$ están fuertemente diferenciados en sus frecuencias. El procedimiento de Wagner y el algoritmo de Unión al Vecino produjeron topologías similares, altamente relacionadas con la distancia geográfica y con la situación taxonómica. La falta de coincidencia entre los patrones de variación y los dos morfos (planas y globosas) presentes en E. exalbida de la bahía Ushuaia no apoyan su reconocimiento taxonómico como entidades genéticas discretas.

Palabras clave: variabilidad alozímica, Eurhomalea, estructura genética, situación taxonómica. 


\section{INTRODUCTION}

Protein electrophoresis techniques have been and continue to be widely used and accepted tools in systematics and population studies (Beaumont \& Beveridge 1984, Zouros \& Foltz 1984, Gardner \& Thompson 1999, Dufresne et al. 2002, Féral 2002). Electrophoretic data are a valuable tool for classifying because the genetic similarities within and between taxa provide phylogenetic information above (Buroker et al. 1979a, 1979b, Lavie et al. 1987, McDonald \& Koehn 1988, McDonald et al. 1991, Gardner \& Thompson 2002) and below the species level (Day \& Bayne 1988, Backeljau et al. 1994, Gallardo \& Carrasco 1996, Gallardo et al. 1998, Dufresne et al. 2002, Gajardo et al. 2002).

Traditionally, three allopatric species of Eurhomalea (E. rufa, E. lenticularis, and E. exalbida) have been recognized in southern South America. The distributional range of $E$. rufa extends from Panama to northern Chile whereas E. lenticularis has a restricted distribution limited to the coast of central Chile. Eurhomalea exalbida has the southernmost and extended distribution, from Chiloé island to Buenos Aires (Carcelles 1950, Osorio et al. 1979, Reid \& Osorio 2000). In spite of being an exploited resource (anonymous 1998), no comparative study has yet been published on the genus. In fact, the few and scattered research on ecological variables, growth and production, reproduction, recruitment rate, survival, and energetic variation have been conducted only at the population level (Urban \& Tesch 1996, Jaramillo et al. 1998, Sousa et al. 1998, Campos et al. 1999, Lomovasky et al. 2001, 2002a, 2002b, Morriconi et al. 2002). Morphological characters in Eurhomalea have shown to be somewhat confusing for systematic purposes (Soot-Ryen 1959, Osorio et al. 1979, Ramírez 1993, Reid \& Osorio 2000). Recent paleontological data suggest that E. exalbida and E. lenticularis should be grouped in a new genus, Retrotapes (Del Río 1997). In addition, two highly distinctive shell morphs are suspect to represent different age groups in E. exalbida from Ushuaia bay, Argentina (Lomovasky personal communication).

Here, the allozymic relationships and the degree of population structuring of Eurhomalea species are examined by electrophoretic markers. Having in mind the morphological differences observed in E. exalbida, we aimed to test whether there was a correspondence between shell morphology and the electromorphic patterns recorded for each one of them.

\section{MATERIAL AND METHODS}

A total of 185 adult Eurhomalea (over $5.5 \mathrm{~cm}$ shell lenght) were collected between March and July of 2001 from four geographic localities throughout coastal southern South America. Tissue sample were stored at $-70{ }^{\circ} \mathrm{C}$. Hepatic glands were excised, homogenized and centrifugated folowing the standard procedures (Gallardo et al. 1996)

Sample designation, geographic coordinates and number of specimens per sample were as follows: (1) E. rufa, Punta Choros (29 $16^{\prime} \mathrm{S}$, $\left.71^{\circ} 33^{\prime} \mathrm{W}\right), \mathrm{n}=25$; (2) E. lenticularis, Algarrobo

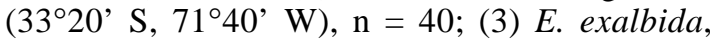

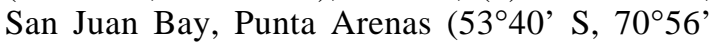
$\mathrm{W}), \mathrm{n}=40$; (4) E. exalbida, Ushuaia Bay, Beagle Channel $\left(54^{\circ} 50^{\prime} \mathrm{S}, 68^{\circ} 16^{\prime} \mathrm{W}\right), \mathrm{n}=80$. The two distinct shell morphs were recognized in the same population from Ushuaia Bay (40 flat and 40 globoid) and were treated as different samples, for operational purposes.

All specimens were scored electrophoretically at 12 enzyme loci as described by Gallardo et al. (1998). The hepatopancreas was excised in $0.05 \mathrm{M}$ Tris-HCL, buffer, $\mathrm{pH} 8.0$ and centrifuged according to Gallardo et al. (1998). The enzymatic systems assayed were: alcohol dehydrogenase (Adh, EC. 1.1.1.1; IUPAC-IUB 1984), glycerol-3-phosphate dehydrogenase $(\alpha$ $\mathrm{Gpd}$, EC. 1.1.1.8), phosphoglucomutase (Pgm, EC. 2.7.5.1), octopine dehydrogenase (Odh, EC. 1.5.1.11), hexokinase ( $H k$, EC. 2.7.1.1), glucosephosphate-isomerase (Gpi, EC. 5.3.1.9), malate dehydrogenase (Mdh, EC. 1.1.1.37), xanthine dehydrogenase (Xdh, EC. 1.2.1.37), isocitrate dehydrogenase (Idh, EC. 1.1.1.42), superoxide dismutase (Sod, EC. 1.15.1.1), lactate dehydrogenase ( $L d h$, EC. 1.1.1.27). Starch geles were stained according to Selander et al. (1971), Harris \& Hopkinson (1976) and Dillon \& Davis (1980). Alleles were designated alphabetically according to their migration relative to the most common allele. For calibration, selected individuals from different localities were run side by side on the same gel. A locus was considered polymorphic if the frequency of the most common allele did not exceed 0.95 . Heterozygosity was derived from the electromorphic genotypes by direct count. Expected heretozygosity was estimated by the method of Levene (1949) for small samples. All this procedures were made using the program BIOSYS 1.0. The inter- and intra-specific genetic relationships between pairs of samples was obtained by Nei's unbiased genetic identity (I; Nei 1978) and by Rogers's modified distance ( $D$; Rogers 1972). The $D$ matrix, bootstrapped 
1,000 times was subsequently used in a phylogenetic analysis using FITCH (Felsenstein 1993). The cumulative results of the FITCH analyses were expressed as a majority-rule consensus tree using CONSENSE. A Wagner tree procedure (based on Rogers $D$ ) was also chosen to depict the genetic relationship among populations (Swofford \& Selander 1989). Wright's (1978) hierarchical analysis of breeding structure for subdivided populations was used to identify sources of spatial differentiation in gene frequencies attributable to substructuring $\left(\mathrm{F}_{\mathrm{ST}}\right)$. Mean estimates of the Fvalues were estimated with FSTAT 1.2 , by jackknifing over loci to reduce the effect of deviant samples (Goudet 1995).

\section{RESULTS}

Although high standard measures of genetic variation were found in Eurhomalea, our estimates are within the limits reported for other bivalves (Ayala et al. 1973, Buroker et al. 1979a, 1979b, Gallardo et al. 1998). Heterozygosity level and percent polymorphism $(\overline{\mathrm{x}}=49.3 \%)$ was high as reflected by the twelve variable loci having up to six different alleles across populations (Table 1). Direct-count heterozygosity fluctuated between 15.8 and 20.7 $\%$ and significant heterozygote deficiency (ranging from three to four loci) was found across the sampled localities (Table 1).

Diagnostic alleles differences were found among the three species at locus Hk- 1 . Nearlyfixed allelic differences between rufa-like, lenticularis-like and exalbida-like samples ocurred at six loci (Adh, $\alpha-G p d, I c d-1, L d h$, $O d h$, and $P g m-3)$. Loci $\alpha-G p d$, and Icd-l were diagnostic for the discrimination of $E$. rufa from the other two species. Locus $O d h$ in $E$. exalbida was fixed or nearly-fixed for allele B, whereas allele A is fixed in E. lenticularis.

Nei's genetic identity was very high among conspecific samples of E. exalbida $(I=$ $0.989)$ but it was much lower at the interspecific level $(I=0.724$ between $E$. exalbida and E. lenticularis). Genetic identity was $67.7 \%$ between E. exalbida and E. rufa and it was $53.8 \%$ between E. lenticularis and E. rufa. Lack of discrimination and high identity values $(I=0.995)$ were obtained between the two sympatric morphotypes of $E$. exalbida.

Three clusters highly consistent with both the geographic location and the specific status of the samples were produced by the Wagner tree. The first one contained the northern sample of E. rufa (Punta Choros); the second was formed by E. lenticularis from Algarrobo, and the third was formed by E. exalbida from San Juan Bay and Ushuaia Bay (not shown). An identical tree topology with high bootstrap support was also obtained with FITCH (Fig. 1).

Low estimates of population substructuring were found within the three samples of $E$. exalbida $\left(\mathrm{F}_{\mathrm{ST}}=0.027\right)$. The migration rate derived from this $\mathrm{F}_{\mathrm{ST}}$ value corresponds to an exchange of nine individuals per generation. Nevertheless, if the five samples are treated as conspecifics, the standardized variance of gene frequencies $\left(\mathrm{F}_{\mathrm{ST}}=0.39\right)$ suggest an exchange rate of 0.4 individuals per generation.

\section{DISCUSSION}

A high variability in allozymic patterns has been reported in marine organisms (Ayala et al. 1973, Campbell et al. 1975, Nevo 1990, Dufresne et al. 2002, Gardner \& Thompson 2002). Mean polymorphism (49\%) and the average heterozygosity level $(18.3 \%)$ is high in Eurhomalea but within the range of other marine invertebrates (Buroker et al. 1979a, 1979b, Nevo et al. 1984, Day \& Bayne 1988, Backeljau et al. 1994, Gallardo \& Carrasco 1996). The observation of an overall deficiency of heterozygotes is a feature common in other studies on more than 50 species of mollusks such as mytilids, pectinids, ostreids and cardids (Nevo et al. 1984).

The electrophoretic data recorded for the total Eurhomalea populations provides further evidence for a generalized heterozygote deficiency at enzymatic loci in bivalves. A number of possible explanations for this deficiency include the presence of null alleles, mis-scoring of gels, inbreeding, aneuplody, the Wahlund effect, non random mating, and selection against heterozygotes (Zouros \& Foltz 1984, Foltz 1986, Zouros et al. 1988, Gaffney et al. 1990, Gardner \& Thompson 1999). Our analyses do not permit an assessment in the detection of the factors responsible for the residual heterozygote deficiencies. Deviation of genotypic proportions may reflect an incorrect procedure for obtaining genotype data, or alternatively, that these populations depart from Hardy Weinberg equilibrium.

A consistent association between geographic distribution and allozymic differentiation was generated by both clustering procedures. Resulting from the alternative fixation or nearlyfixation of alternative alleles, these topologies reflect also a clear segregation into discrete 
TABLE 1

Allelic frequencies, sample size, and estimates of genetic variability for 12 polymorphic loci assayed in 5 sample localities of Eurhomalea. Localities: (1) Punta Choros, (2) Algarrobo, (3) San

Juan Bay, Punta Arenas, (4) Ushuaia Bay (Globoid), (5) Ushuaia Bay (Flat). Bold-marked genotypes for this locus and sample deviate significantly from Hardy-Weinberg expectations

Frecuencias alélicas, tamaño muestreal y estimaciones de variabilidad genética para 12 loci polimórficos ensayados en cinco localidades de Eurhomalea. Localidades: (1) Punta Choros, (2) Algarrobo, (3) Bahía San Juan,

Punta Arenas, (4) Bahía Ushuaia (globosas), (5) Bahía Ushuaia (planas). En negrita se marcan los genotipos de los locus que se desvían significativamente de lo esperado bajo el equilibrio de Hardy-Weinberg

\begin{tabular}{|c|c|c|c|c|c|}
\hline \multirow[t]{2}{*}{ Locus } & \multicolumn{5}{|c|}{ Locality number } \\
\hline & $\begin{array}{c}1 \\
\text { Pta. Choros } \\
(\text { E. rufa }) \\
(\mathrm{n}=25)\end{array}$ & $\begin{array}{c}2 \\
\text { Algarrobo } \\
\begin{array}{c}\text { (E. lenticularis) } \\
(\mathrm{n}=40)\end{array}\end{array}$ & $\begin{array}{c}3 \\
\text { Pta. Arenas } \\
(\text { E. exalbida) } \\
(\mathrm{n}=40)\end{array}$ & $\begin{array}{c}4 \\
\text { Ushuaia (g) } \\
\begin{array}{c}\text { E. exalbida }) \\
(\mathrm{n}=40)\end{array}\end{array}$ & $\begin{array}{c}5 \\
\text { Ushuaia (f) } \\
\begin{array}{c}\text { E. exalbida }) \\
(\mathrm{n}=40)\end{array}\end{array}$ \\
\hline$A d h$ & 0.688 & 0.563 & 1.000 & 1.000 & 1.000 \\
\hline A & 0.312 & 0.437 & 0.000 & 0.000 & 0.000 \\
\hline $\begin{array}{l}\alpha-G p d \\
\mathrm{~A} \\
\mathrm{~B}\end{array}$ & $\begin{array}{l}1.000 \\
0.000\end{array}$ & $\begin{array}{l}0.000 \\
1.000\end{array}$ & $\begin{array}{l}0.000 \\
1.000\end{array}$ & $\begin{array}{l}0.000 \\
1.000\end{array}$ & $\begin{array}{l}0.000 \\
1.000\end{array}$ \\
\hline $\begin{array}{l}H k-1 \\
\text { A } \\
\text { B } \\
\text { C }\end{array}$ & $\begin{array}{l}0.000 \\
1.000 \\
0.000\end{array}$ & $\begin{array}{l}0.000 \\
0.000 \\
1.000\end{array}$ & $\begin{array}{l}1.000 \\
0.000 \\
0.000\end{array}$ & $\begin{array}{l}1.000 \\
0.000 \\
0.000\end{array}$ & $\begin{array}{l}1.000 \\
0.000 \\
0.000\end{array}$ \\
\hline $\begin{array}{l}I d h \\
\mathrm{~A} \\
\mathrm{~B}\end{array}$ & $\begin{array}{l}0.000 \\
1.000\end{array}$ & $\begin{array}{l}1.000 \\
0.000\end{array}$ & $\begin{array}{l}1.000 \\
0.000\end{array}$ & $\begin{array}{l}1.000 \\
0.000\end{array}$ & $\begin{array}{l}1.000 \\
0.000\end{array}$ \\
\hline $\begin{array}{l}L d h \\
\text { A } \\
\text { B } \\
\text { C }\end{array}$ & $\begin{array}{l}0.000 \\
0.562 \\
0.438\end{array}$ & $\begin{array}{l}1.000 \\
0.000 \\
0.000\end{array}$ & $\begin{array}{l}0.000 \\
0.350 \\
0.650\end{array}$ & $\begin{array}{l}0.000 \\
0.325 \\
0.675\end{array}$ & $\begin{array}{l}0.000 \\
0.363 \\
0.637\end{array}$ \\
\hline $\begin{array}{l}M d h \\
\text { A } \\
\text { B } \\
\text { C }\end{array}$ & $\begin{array}{l}0.667 \\
0.333 \\
0.000\end{array}$ & $\begin{array}{l}0.188 \\
0.400 \\
0.412\end{array}$ & $\begin{array}{l}0.188 \\
0.300 \\
0.512\end{array}$ & $\begin{array}{l}0.250 \\
0.400 \\
0.350\end{array}$ & $\begin{array}{l}0.188 \\
0.375 \\
0.437\end{array}$ \\
\hline $\begin{array}{l}O d H \\
\mathrm{~A} \\
\mathrm{~B} \\
\mathrm{C}\end{array}$ & $\begin{array}{l}0.521 \\
0.271 \\
0.208\end{array}$ & $\begin{array}{l}1.000 \\
0.000 \\
0.000\end{array}$ & $\begin{array}{l}0.000 \\
0.975 \\
0.025\end{array}$ & $\begin{array}{l}0.000 \\
1.000 \\
0.000\end{array}$ & $\begin{array}{l}0.000 \\
1.000 \\
0.000\end{array}$ \\
\hline $\begin{array}{l}G p i \\
\text { A } \\
\text { B } \\
\text { C } \\
\text { D } \\
\text { E } \\
\text { F }\end{array}$ & $\begin{array}{l}0.042 \\
0.021 \\
0.771 \\
0.104 \\
0.021 \\
0.042\end{array}$ & $\begin{array}{l}0.000 \\
0.000 \\
0.013 \\
0.300 \\
0.512 \\
0.175\end{array}$ & $\begin{array}{l}0.150 \\
0.200 \\
0.375 \\
0.200 \\
0.075 \\
0.000\end{array}$ & $\begin{array}{l}0.162 \\
0.587 \\
0.013 \\
0.225 \\
0.013 \\
0.000\end{array}$ & $\begin{array}{l}0.175 \\
0.563 \\
0.000 \\
0.250 \\
0.013 \\
0.000\end{array}$ \\
\hline $\begin{array}{l}\text { Pgm-2 } \\
\text { A } \\
\text { B } \\
\text { C } \\
\text { D }\end{array}$ & $\begin{array}{l}0.000 \\
0.792 \\
0.208 \\
0.000\end{array}$ & $\begin{array}{l}0.000 \\
0.400 \\
0.350 \\
0.250\end{array}$ & $\begin{array}{l}0.213 \\
0.275 \\
0.512 \\
0.000\end{array}$ & $\begin{array}{l}0.225 \\
0.350 \\
0.425 \\
0.000\end{array}$ & $\begin{array}{l}0.225 \\
0.250 \\
0.525 \\
0.000\end{array}$ \\
\hline $\begin{array}{l}\mathrm{Pgm}-3 \\
\mathrm{~A} \\
\mathrm{~B} \\
\mathrm{C}\end{array}$ & $\begin{array}{l}0.000 \\
1.000 \\
0.000\end{array}$ & $\begin{array}{l}0.450 \\
0.313 \\
0.237\end{array}$ & $\begin{array}{l}0.363 \\
0.462 \\
0.175\end{array}$ & $\begin{array}{l}0.575 \\
0.200 \\
0.225\end{array}$ & $\begin{array}{l}0.375 \\
0.450 \\
0.175\end{array}$ \\
\hline $\begin{array}{l}\text { Sod-1 } \\
\text { A } \\
\text { B } \\
\text { C } \\
\text { D }\end{array}$ & $\begin{array}{l}0.146 \\
0.771 \\
0.084 \\
0.000\end{array}$ & $\begin{array}{l}0.538 \\
0.387 \\
0.075 \\
0.000\end{array}$ & $\begin{array}{l}0.275 \\
0.325 \\
0.350 \\
0.050\end{array}$ & $\begin{array}{l}0.213 \\
0.337 \\
0.262 \\
0.188\end{array}$ & $\begin{array}{l}0.150 \\
0.388 \\
0.412 \\
0.050\end{array}$ \\
\hline $\begin{array}{l}X d h-2 \\
\text { A } \\
\text { B }\end{array}$ & $\begin{array}{l}0.333 \\
0.667\end{array}$ & $\begin{array}{l}0.325 \\
0.675\end{array}$ & $\begin{array}{l}0.663 \\
0.337\end{array}$ & $\begin{array}{l}0.650 \\
0.350\end{array}$ & $\begin{array}{l}0.725 \\
0.275\end{array}$ \\
\hline $\begin{array}{l}\text { Mean number of alleles/locus } \\
\text { Percent of loci polymorphic } \\
\text { Mean heterozygosity }\end{array}$ & $\begin{array}{r}1.9 \\
53.3 \\
15.8\end{array}$ & $\begin{array}{r}1.9 \\
46.7 \\
16.3\end{array}$ & $\begin{array}{r}2.1 \\
53.3 \\
20.2\end{array}$ & $\begin{array}{r}2.0 \\
46.7 \\
18.5\end{array}$ & $\begin{array}{r}1.9 \\
46.7 \\
20.7\end{array}$ \\
\hline
\end{tabular}




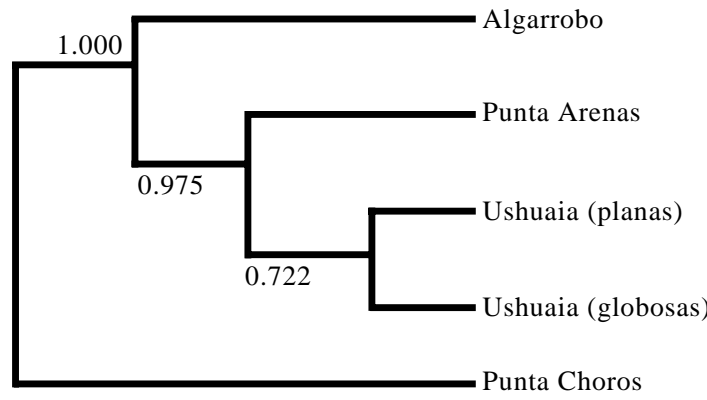

Fig. 1: Majority-rule consensus tree derived from a distance matrix (neighbor-joining) of five populations of Eurhomalea. Bootstrap values shown at nodes are a measure of repeatability based of 1,000 bootstrap iterations.

Árbol de consenso mayoritario derivado de una matriz de distancia (neighbor joining) de cinco poblaciones de Eurhomalea. Los valores de bootstrap mostrados en los nodos son una medida de repetitividad basada en 1.000 iteraciones.

genetic units. In contrast, low intraspecific $\mathrm{F}_{\mathrm{ST}}$ estimates and Nei's distance values reflect regional cohesiveness and essential lack of population substructuring in E. exalbida. The high intraspecific estimates of gene flow $(\mathrm{Nm}=$ 9) suggest that either for a two-dimensional stepping stone or an island model, random differentiation through genetic drift is prevented (Slatkin 1985).

Previous electrophoretic surveys have established that Nei's mean genetic identity is $\leq 0.85$ in about $97 \%$ of interspecific comparisons, whereas in $98 \%$ of intraspecific comparisons is more than 0.85 (Ayala 1975, Skibinski et al. 1980, Sarver et al. 1992, Backeljau et al. 1994). Our results for the conspecific populations of E. exalbida was $I=$ 0.989 whereas the same parameter estimated at the interspecific level fluctuated between 0.538 and 0.724 . These results are totally consistent with the morphological and distributional criteria used for species recognition in Eurhomalea as supported by its correspondence with the demarcation limits of allozymic data above mentioned.

Based on the evolutionary species concept that emphasizes its genetic integrity over hybridization (Wiley 1981), allozymic studies have recognized sibling species by the presence of fixed allelic differences and large genetic distances (Chambers 1978, Woodruff 1988). Our data also show that Eurhomalea species are allozymically different as demostrated in other molluscan taxa (Liu et al. 1991). The intrapopulational morphs of shell shape (flat and globoid) found in E. exalbida from Ushuaia, assumed to represent reproductively isolated units has no genetic basis to substantiate their taxonomic recognition. Most probably, these morphs represent age groups having distinctive growth rates (Lomovasky, unpublished data). Accordingly, this trait should be considered as a polymorphic one.

Since fishery management plans require basic biological knowledge to determine the conservation status of any exploited resource, the existence of three Eurhomalea species and a detailed knowledge of its conservation status should be considered in future governmental actions.

\section{ACKNOWLEDGMENTS}

This research was partially supported by the German-Argentinean Bilateral Cooperation Program in Science and Technology (BMBF and SECyT) (ARG 001/99 MAR-AL/A99UXIII/12) and by grant FNC 1010727 to MHG, and FNC 1951202 to EC. The logistic support and sample recollection of T. Brey, B. Campos, C. Guisado, and C. Ríos is greatly appreciated.

\section{LITERATURE CITED}

ANONYMOUS (1998) Anuario estadístico de pesca. Servicio Nacional de Pesca, Ministerio de Economía, Fomento y Reconstrucción, Gobierno de Chile, Santiago, Chile. 158 pp.

AYALA FJ, D HEDGEHOCK, GS ZUMWALT \& JW VALENTINE (1973) Genetic variation in Tridacna maxima, an ecological analog of some unsuccessful evolutionary lineages. Evolution 27: 177-191.

AYALA FJ (1975) Genetic differentiation during the speciation process. Evolutionary Biology 8: 1-78.

BACKELJAU T, P BOUCHET, S GOFAS \& L DE BRUYN (1994) Genetic variation and distribution of the veneriid clam Chamelea gallina. Journal of Marine Biological Association of the United Kingdom 74: 211-223.

BEAUMONT AR \& CM BEVERIDGE (1984) Electrophoretic survey of genetic variation in Pecten maximus, Chlamys opercularis, $C$. varia and $C$. distorta from the Irish Sea. Marine Biology 81: 299-306.

BUROKER NE, WK HERSHBERGER \& KK CHEW (1979a) Population genetics of the Family Ostreidae. I. Intraespecific studies of Crassostrea gigas and Saccostrea commercialis. Marine Biology 54: 157-169.

BUROKER NE, WK HERSHBERGER \& KK CHEW (1979b) Population genetics of the Family Ostreidae. II. Interespecific studies of the Genera Crassostrea and Saccostrea. Marine Biology 54: 171-184.

CAMPBELL CA, JW VALENTINE \& FJ AYALA (1975) High genetic variability in a population of Tridacna maxima from the Great Barrier Reef. Marine Biology 33: 341-345. 
CAMPOS B, D BROWN, L DURÁN, C MELO \& J URBAN (1999) Estudio de edad y reproducción del recurso almeja en la Cuarta y Quinta regiones. Informe Final, Proyecto FIP-IT 97-32. Subsecretaría de Pesca, Ministerio de Economía, Gobierno de Chile, Santiago, Chile. 225 pp.

CARCELLES (1950) Catálogo de los moluscos marinos de la Patagonia. Revista del Museo Argentino de Ciencias Naturales (Argentina) 2: 41-100.

CHAMBERS SM (1978) An electrophoretically detected sibling species of "Goniobasis floridensis" (Mesogastropoda, Pleuroceridae). Malacología 17: 157-162.

DAY AJ \& BL BAYNE (1988) Allozyme variation in populations of the dog-whelk Nucella lapillus (Prosobranchia: Muricacea) from the south west peninsula of England. Marine Biology 99: 93-100.

DEL RÍO CJ (1997) Cenozoic biogeographic history of the eurhythermal genus Retrotapes, new genus (Subfamily Tapetinae) from southern South America and Antarctica. Nautilus 110 : 77-93.

DILLON R \& G DAVIS (1980) The goniobasis of South Virginia and north-western North Carolina: genetics and shell morphometric relationship. Malacologia 20: 83-98.

DUFRESNE F, BOURGET E \& BERNATZCHEZ L (2002) Differential patterns of spatial divergence in microsatellite and allozyme alleles: further evidence for locus specific selection in the acorn barnacle, Semibalanus balanoides? Molecular Ecology 11: 113-123.

FELSENSTEIN J (1993) PHYLIP (Phylogenetic inference package). Version $3.5 \mathrm{c}$. University of Washington, Seattle, Washington, USA. $180 \mathrm{pp}$.

FÉRAL JP (2002) How useful are genetic markers in attempts to understand and manage marine biodiversity. Journal of Experimental Marine Biology and Ecology 268: 121-145

FOGARTY JM, MP SISSENWINE \& E COHEN (1991) Recruitment variability and the dynamics of exploited marine populations. Trends in Ecology and Evolution 6: 241-245.

FOLTZ D (1986) Null alleles as a possible cause of heterozygote deficiencies in the oyster Crassostrea virginica and other bivalves. Evolution 40: 869-870.

GAFFNEY PM, TM SCOTT, RK KOEHN \& WJ DIEHL (1990) Interrelationships of heterozygosity, growth rate and heterozygote deficiencies in the Coot clam, Mulinia lateralis. Genetics 124: 687-699.

GAJARDO G, JM CANCINO \& JM NAVARRO (2002) Genetic variation and population structure in the marine snail Chorus giganteus (Gastropod: Muricidae), an overexploited endemic resource from Chile. Fisheries Research 55: 329-333.

GALLARDO M \& J CARRASCO (1996) Genetic cohesiveness among population of Concholepas concholepas (Gastropoda, Muricidae) in southern Chile. Journal of Experimental Marine Biology and Ecology 197: 237-249.

GALLARDO M, L PEÑALOZA \& E CLASING (1998) Gene flow and allozymic population structure in the clam Venus antiqua (King \& Broderip), (Bivalvia, Veneriidae) from southern Chile. Journal of Experimental Marine Biology and Ecology 230: 193-205.

GARDNER JP \& RJ THOMPSON (1999) High levels of shared allozyme polymorphism among strongly differentiated congeneric clams of the genus Astarte (Bivalvia: Mollusca). Heredity 82: 89-99.

GOUDET J (1995) FSTAT versión 1.2, a computer program to calculate F-statistics. Journal of Heredity 86: 485-486.
HARRIS H, DA HOPKINSON (1976) Handbook of enzyme electrophoresis in human genetics, supplement. North Holland Publishing Company, Amsterdam, The Netherlands. 115 pp.

IUPAC-IUB: ENZYME NOEMNCLATURE (1984) Recommendations of the International Union of Pure and Applied Chemistry and the International Union of Biochemistry. Elsevier Publishing Co., Amsterdam, The Netherlands. 167 pp.

JARAMILLO E, E CLASING, M AVELLANAL, P QUIJÓN, P RUBILAR \& G JEREZ (1998) Estudio biológico pesquero de los recursos almeja, navajuela y huepo en la VIII y $\mathrm{X}$ regiones. Informe Final, Proyecto FIP 96-46. Subsecretaría de Pesca, Ministerio de Economía, Gobierno de Chile, Santiago, Chile. 357 pp.

KOEHN RK, JG HALL, DJ INNES \& AJ ZERA (1984) Genetic differentiation of Mytilus edulis in eastern North America. Marine Biology 79: 117-126.

LAVIE B, R NOY \& E NEVO (1987) Genetic variability in the marine gastropods Patella coerulea and Patella aspera: patterns and problems. Marine Biology 96: 367-370.

LEVENE H (1949) On a matching problem arising in genetics. Annual Mathematics Statistics 20: 91-94.

LIU LL, DW FOLTZ \& WB STICKLE (1991) Genetic population structure of the southern oyster drill Stramonita (= Thais) haemostoma . Marine Biology 111: 71-79.

LOMOVASKY BJ, E MORRICONI \& J CALVO (2001) Energetics variation of the striped clam Eurhomalea exalbida (Chemnitz, 1795) in Ushuaia Bay, Beagle Channel $\left(54^{\circ} 50^{\prime} \mathrm{S}\right)$. Journal of Shellfish Research 20: $1089-1094$.

LOMOVASKY BJ, T BREY, E. MORRICONI \& J CALVO (2002a) Growth and production of the veneriid bivalve Eurhomalea exalbida in the Beagle Channel, Tierra del Fuego. Journal of Sea Research 48: 209-216.

LOMOVASKY BJ, E MORRICONI, T BREY \& J CALVO (2002b) Individual age and connective tissue lipofucsin in the hard clam Eurhomalea exalbida. Journal of Experimental Marine Biology and Ecology 276: 83-94.

MCDONALD JH \& KK KOEHN (1988) The mussels Mytilus galloprovincialis and $M$. trossulus on the Pacific coast of North America. Marine Biology 99: 111-118.

MCDONALD JH, R SEED \& RK KOEHN (1991) Allozymes and morphometric characters of three species of Mytilus in the Northern and Southern Hemispheres. Marine Biology 111: 323-333.

MORRICONI E, BJ LOMOVASKY, J CALVO \& T BREY (2002) The reproductive cycle of Eurhomalea exalbida (Chmenitz, 1795) (Bivalvia: Veneridae) in Ushuaia Bay (5450' S), Beagle Channel (Argentina). Invertebrate Reproduction \& Development 42: 61-68.

NEI M (1978) Estimation of average heterozygosity and genetic distance from a small number of individuals. Genetics 89: 583-590.

NEVO E (1990) Molecular evolutionary genetics of isozymes: pattern, theory, and application. In: Ojita $\mathrm{Z}$ (ed) Isozymes: structure, function and use in biology and medicine. 701-742. Wiley-Liss, Inc., New York, New York, USA.

NEVO E, A BEILES \& R BEN-SHLOMO (1984) The evolutionary significance of genetic diversity: Ecological, demographic and life history correlates. Lecture Notes in Biomathematics 53: 13-213.

OSORIO C, J ATRIA \& S MANN (1979) Moluscos Marinos de importancia económica en Chile. Biología Pesquera (Chile) 11: 3-47. 
RAMÍREZ J (1993) Moluscos de Chile: Bivalvia. Cuarto volumen. Private Publication, Santiago, Chile. 286 Pp.

RAYMOND M \& F ROUSSET (1995) An exact test for population differentiation. Evolution 49: 1280-1283.

REID DG \& C OSORIO (2000) The shallow-water marine Mollusca of the Estero Elefantes and Laguna San Rafael, southern Chile. Bulletin of the Natural History Museum of London (United Kingdom) 66: 109-146.

ROGERS JS (1972) Measures of genetic similarity and genetic distance. University of Texas publication No 7213: 145-153.

SARVER SK, MC LANDRUM \& DW FOLTZ (1992) Genetics and taxonomy of ribbed mussels (Geukensia spp.). Marine Biology 113: 385-390.

SELANDER RM, S SMITH, W YANG, W JOHNSON, J GENTRY (1971) Biochemical polymorphism and systematics of Peromyscus. I. Variation in the old field mouse Peromyscus poloinatus. University of Texas Publication (USA) 7103: 49-90.

SKIBINSKI DOF, TF CROSS \& JA BEARDMORE (1980) Electrophoretic investigation of systematic relationship in the marine mussel Modiolus modiolus L., Mytilus edulis L. and Mytilus galloprovincialis Lmk. (Mytilidae; Mollusca). Biological Journal of the Linnean Society 13: 65-73.

SLATKIN M (1985) Rare alleles as indicators of gene flow. Evolution 39: 53-65.

SOOT-RYEN T (1959) Pelecypoda. Reports of the LundUniversity of Chile Expedition 1948-1949. 35 Pelecypoda. Lunds Universitets Arsskrift (Sweden) 55: $1-86$
SOUSA M, R GUERRA, E OLIVEIRA \& A TORRES (1998) Comparative PTA staining of molluscan spermatozoa. Journal of Submicroscopic Cytology Pathology 30: 183-187.

SWOFFORD DL \& RB SELANDER (1989) BIOSYS-1: a computer program for the analysis of allelic variation in population genetics and biochemical systematics. Journal of Heredity 72: 281-283.

URBAN JH \& C TESCH (1996) Aspects of the population dynamics of six bivalve species from Southern Chile. Results of the "Victor Hensen" cruise to the Magellan Strait and the Beagle Channel in October/ November 1994. Archives of Fisheries and Marine Research 44: 243-256.

WILEY EO (1981) Phylogenetics-the theory and practice of phylogenetics systematics. John Wiley \& Sons, New York, New York, USA. 345 pp.

WRIGHT S (1978) Evolution and the genetics of natural populations. University of Chicago Press, Chicago, Illinois, USA. 580 pp.

WOODRUFF DS, KC STAUB, EC VIYANANT \& HC YUAN (1988) Genetic variation in Oncomelania hupensis: Schistosoma japonicum transmiting snails in China and the Phillipines are distinct species. Malacología 29: 347-361.

ZOUROS E \& DW FOLTZ (1984) Possible explanation of heterozygote deficiency in bivalve mollusks. Malacologia 25: 583-591.

ZOUROS E, M ROMERO-DOREY \& AT MALLET (1988) Heterozygosity and growth in marine bivalves: further data and possible explanations. Evolution 42: 1332-1341. 